\title{
International Trade and Employment: A Quantile Regression Approach
}

\author{
Hoi Van Ha \\ University of Economics and Business, Vietnam National University, Hanoi, Vietnam \\ Tuyen Quang Tran \\ University of Economics and Business, Vietnam National University, Hanoi, Vietnam
}

\begin{abstract}
Existing studies on the relationship between international trade and manufacturing employment often use a mean regression approach and focus mainly on developed countries. Few studies have applied a quantile regression approach to examine this relationship in developing countries. To fill the gap, this study considers, for the first time, the impact of rising international trade on employment in a developing country, Vietnam. Using an unbalanced panel dataset for the 2010 2015 period, we find a positive linkage between international trade and firm employment when ordinary least square is used. However, by using a fixed-effect quantile approach, we find that international trade is negatively linked with employment for firms in the low employment percentile but positively related with firms in the high employment percentile. Our results also show that previous studies at the national or industry level may have produced biased results by not controlling for the heterogeneity of firm characteristics.
\end{abstract}

JEL Classifications: F1, F14

Keywords: International Trade, Labor Demand, Northwest, Vietnam

\footnotetext{
* Corresponding Author: Tuyen Quang Tran; University of Economics and Business, Vietnam National University, Hanoi, Building E4, 144 Xuan Thuy Street, Cau Giay District, Hanoi, Vietnam, Tel: (84.4)237547506; Fax (84.24)37546765, email: tuyentq@vnu.edu.vn

Co-author: Hoi Van Ha; University of Economics and Business, Vietnam National University, Hanoi, Building E4, 144 Xuan Thuy Street, Cau Giay District, Hanoi, Vietnam, Tel: (84.4)237547506; Fax (84.24) 37546765, email: hoihv@vnu.edu.vn 


\section{Introduction}

Theoretically, there are important mechanisms that explain how international trade affects employment. The first, drawing inspiration from the Heckscher-OhlinSamuelson model, shows that international trade affects labor demand in two ways; (1) the scale effect shows that the greater the international trade integration in a country, the higher is the output of the export sector, which in turn creates a higher demand for labor; (2) substitution effects show that increase in international trade coinciding with rising import competition will result in substitution of domestic production, and this will lead to a fall in employment in the import sector.

Another theoretical mechanism is explained by Greenaway et al. (1999), who argued that participation in international trade may help trading firms realize higher productivity compared with their non-trading counterparts. This higher productivity encourages firms to reduce their workforce and exclude workers of low ability (Chand and Sen 2002, Helpman, Itskhoki, and Redding 2010).

While theoretical predictions are readily understood, empirical findings regarding the role that international trade plays in employment are inconclusive. Although a positive correlation between international trade and employment has been found for developing countries (Fu and Balasubramanyam 2004, Sen 2002). In contrast, Greenaway et al. (1999) investigating the effect of international trade on employment using longitudinal industry-level data, found that there is a negative relationship between international trade and employment, with the controlling variables at the industry-characteristic level. Other studies reveal that international trade has an insignificant impact on employment (Turrini 2002).

This lack of clarity regarding the link between international trade and firm-level employment is what motivates our efforts to examine this topic for Vietnam. Vietnam is an interesting case because it is a country with a low level of economic advancement; however, it has also experienced economic transition and strong growth in both imports and exports since signing the bilateral trade agreement with the US in 2001 and gaining World Trade Organization (WTO) accession in 2007.

A common belief in Vietnam is that while an increase in exports has a positive impact on labor demand, the link between imports and employment growth is weak (Kien and Heo 2009). However, we argue that studies that use industry- level data or country-level data have shortcomings. Controlling for the characteristics of heterogeneity of firms 
in the economy is impossible when one uses aggregated data (Kasahara and Rodrigue 2008). Furthermore, Halpern, Koren, and Szeidl (2005) show that macro-level data may suffer from problems caused by omitted variables and reserve causality.

Regarding methodology, most existing studies use the averages approaches such as Ordinary Least Squares (OLS) or Fixed Effect (FE) estimations. However, if firms are heterogeneous, the influence of international trade may be different along different points on the outcome distribution (Wagner 2006).

Our study makes a number of unique contributions to the literature. It draws upon a unique panel dataset to provide the first evidence at the firm level of the impact of international trade on firm employment in Vietnam. In addition, using the OLS or the least absolute deviation approach only accounts for the marginal effects of the covariates on the conditional mean (median) function of firm employment. Such regressions sidestep the potentially heterogeneous structure of the variables in conditional distribution (Vu, Holmes, Lim, and Tran 2014). In addition, the results from the quantile approach are robust to the presence of outliers (Kizhakethalackal et al. 2013). Also, by using fixed effect quantile regression estimations, we expect to provide a detailed picture of the impact of international trade along the entire distribution of firm employment. Our results show that international trade has a negative effect on firm employment in the lowest quantile but a positive one in higher quantiles. Hence, our results have the potential to reconcile the ambiguity in the literature. The remainder of the paper is organized in four parts. Section II sets the background for this study. Section III explains the data sources and the methodology, while Section IV discusses the empirical results. The final section summarizes the main findings.

\section{Background}

This section presents the discussion on how and why rising international trade has an impact on firm-level employment in Vietnam. We then present an overview of Vietnamese international trade and employment in the 2000s.

While the boom in Chinese exports may be one of the biggest shocks to international trade in the early $21^{\text {st }}$ century, it is also the reason customers around the world enjoy lower prices, especially for low-tech products. Meanwhile, increase in Chinese exports 
has adversely affected countries or industries that produce similar products. Vietnam has felt more of the impact of cheap imports from China. As shown by Doan, Nguyen, Vu, Tran, and Lim (2016), Vietnam's imports from world increased from 0.22 percent in 1998 to 0.6 percent in 2009, but Vietnam's imports from China rose even faster. They stood at 4 percent of total Vietnamese imports in 1998 but have risen to almost 25 percent in recent years. Such imports can displace or crowd out domestic production. Rising imports may cause local firms to lose market shares to imported goods, thus reducing the scale of production and affecting employment negatively because firms lose scale efficiency.

Vietnamese manufacturing firms face intense competition from China. Unlike most developed countries, in developing economies like Vietnam, the stock of capital and skilled labor is scarce (Doan et al. 2016). Hence, these scarcities restrain firms from upgrading their products and provide little incentive for investments in more advanced technologies that can effectively leverage the availability of cheap labor. Hence, they often produce goods that are similar to those imported from China and presumably run low-productivity and low-skilled labor-intensive plants (Vu, Holmes, Tran, and Lim 2016). Thus, rising import competition from China may be negatively associated with employment growth in Vietnam.

In terms of the linkages between export expansion and firm employment, previous studies show that an increase in exporting volumes can lead to higher levels of derived labor demand, especially for transitional economies such as Vietnam (Kien 2015). This can be explained by that most of the export goods are labor-intensive products such as textiles, apparel, footwear, and furniture (Kien 2015, Vu, Lim, Holmes, and Doan 2013). Hence, export promotion has allowed these economies to exploit the comparative advantages of producing labor-intensive goods. Thus, expansion of exports becomes an important factor in promoting employment growth.

With regard to international trade in Vietnam, Figure 1 shows that there was a significant growth in Vietnamese trade activities, from nearly 15.7 billion US dollars in 2000 to nearly 85 billion US dollars in 2015. Figure 1 also displays three important milestones that have affected the growth of Vietnam's international trade through the 2010 2015 period. The trade agreement with the US in 2001 marked the first important step toward boosting the trade relationship between the two countries since 2000. In addition, imports and exports in Vietnam continued to grow in the period following its admittance into the WTO in 2007. Finally, trading value witnessed a drop in 2009 because of global crises; however, clear signs of a quick recovery were seen in 
subsequent years.

\section{Figure 1. International trade and employment status in Vietnam}

(2000 2015)

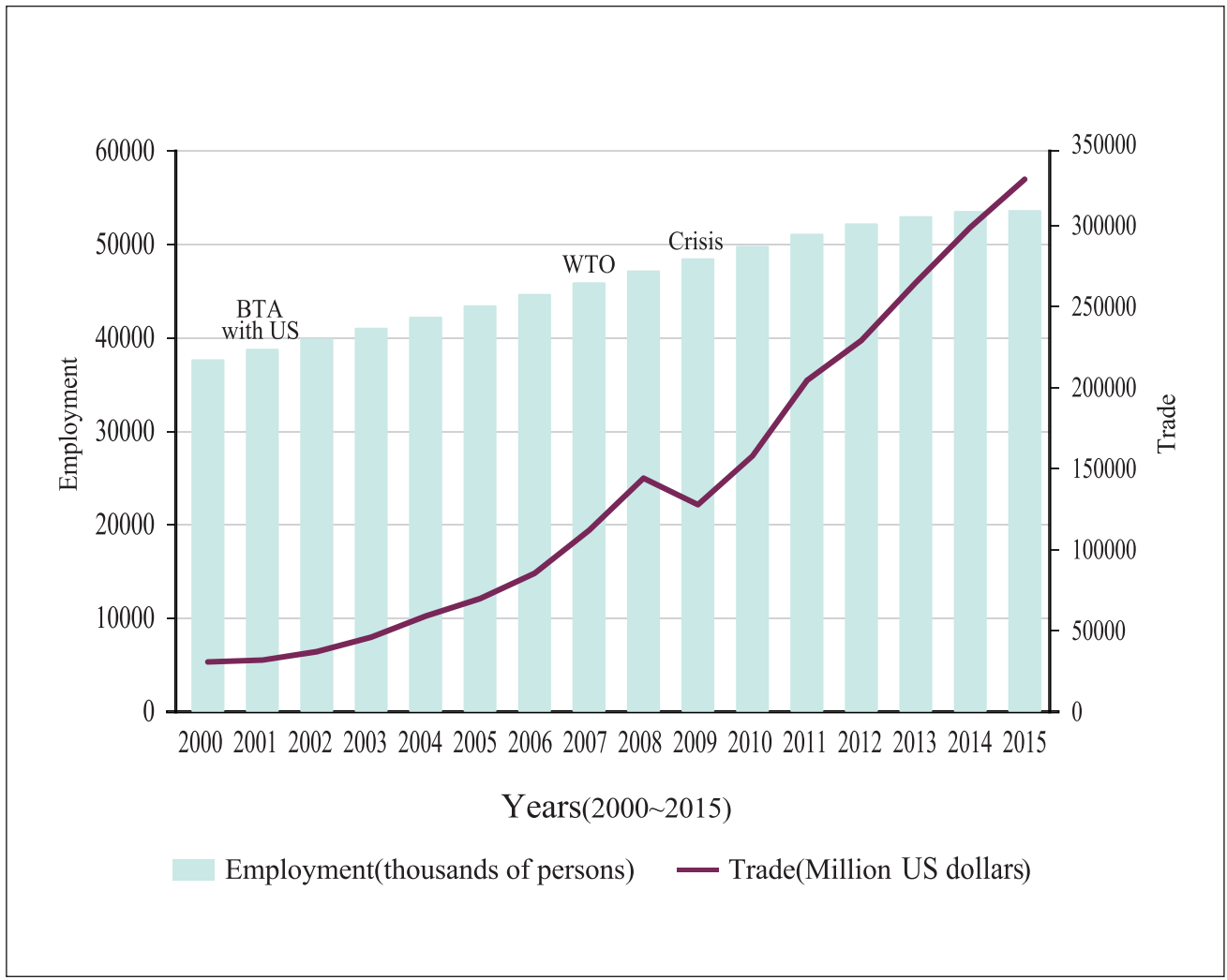

(Source) Statistical Yearbook (various issues) from Vietnam General Statistical Offices.

With regard to international trade in Vietnam, Figure 1 shows that there was a significant growth in Vietnamese trade activities, from nearly 15.7 billion US dollars in 2000 to nearly 85 billion US dollars in 2015. Figure 1 also displays three important milestones that have affected the growth of Vietnam's international trade through the 2010 2015 period. The trade agreement with the US in 2001 marked the first important step toward boosting the trade relationship between the two countries since 2000 . In addition, imports and exports in Vietnam continued to grow in the period following its admittance into the WTO in 2007. Finally, trading value witnessed a drop in 
2009 because of global crises; however, clear signs of a quick recovery were seen in subsequent years.

Figure 1 also shows that employment growth changed significantly from 37.075 thousands of persons to around 52.840 thousands of persons, resulting in a $43 \%$ increase over the 2000 2015 period. Naturally, it accompanies a noticeable sectoral changes. Vietnam's growing international trade in recent years and the mixed findings of empirical results have motivated us to examine if international trade has an effect on firm-level employment. Equally importantly, the underlying mechanism of it requires our investigation.

\section{Data and Econometric Models}

\section{A. Data}

To measure the effect of international trade on firm-level employment in Vietnam's manufacturing sector, we use the Enterprise Censuses of Vietnam (EC). This annual, nationwide census is carried out by the General Statistics Office (GSO) through its network of offices in the provinces and districts. All types of ownership, state-owned, collective, privately owned, and foreign-owned, are covered in the census. The number of observations in EC 2011 and EC 2012 was 305,345 and 339,287, respectively. The census produced panel data, with detailed information on firms' business activities and firm performance. The database also included the main industries, the number of workers, the number of male and female workers, the number of workers with social insurance, labor costs, assets, tax, production costs, turnover, and profits of firms. In addition, it had data on technology, innovation, the number of computers, website availability and internet connection, e-commerce, and application of new technology in production. Most importantly, the EC has data on international trade at the firm level. All this information combined allows us to test the role of international trade in firm-level employment nationwide.

This study focuses only on the manufacturing sector from 2010 to the present because panel data on international trade are only available from 2010. In addition, the tax code is used as a firm identifier to merge the data, thus, firms without a tax code are excluded. 


\section{B. Econometric strategies}

To investigate the impact of exposure to international trade on firm-level employment, we model labor demand, following standard theoretical models, as follows:

$$
\ln L_{i j t}=\beta o+\beta_{1} \text { international trade } e_{j t}+\beta_{2} \ln Q_{i j t}+\beta_{3} \ln W_{i j t}+\beta_{4} Z_{i j t}+\lambda_{t}+\lambda_{j}+\lambda_{i}+\mathrm{u}_{i j t}
$$

where $\ln L_{i j t}$ is the natural $\log$ of employment of firm $i$ in industry $j$ at time $t$. Following Kurz and Senses (2016), we categorize the international trading statuses of firms as nontraders (firms that do not engage in international trade), traders (firms that participate in both exports and imports), exporters only (firms that only export and do not import), and importers only (firms that only import and do not export). The sets of control variables at the firm level include average wage $\left(W_{i j t}\right)$ and real output $\left(Q_{i t}\right)$. Vector $Z_{i j t}$ represents the set of independent variables such as firm ownership; controlling for employment differences by type of ownership; and dummies for industry $\left(\lambda_{j}\right)$, firm $\left(\lambda_{i}\right)$, and year $\left(\lambda_{t}\right)$ fixed effects to account for unobservable technology shocks and other macroeconomic variations.

Mean approaches such as OLS, FE, or Generalized Method of Moments (GMM) are methodologies that most studies have used for examining the role of international trading status in firm-level employment (e.g., Greenaway, Hine, and Wright 1999, Ko, Rangkakulnuwat, and Paweenawat 2015). However, while mean approaches estimate the conditional mean of the outcome distribution, the effect might be different across points on the outcome distribution of firms. According to Buchinsky (1994, p. 453), "on the average' has never been a satisfactory statement with which to conclude a study on heterogeneous populations."

When the normality of residual distributions of each quantile is satisfied, the model specifies the $q^{\text {th }}$ quantile $(0<q<1)$ of conditional distribution of the dependent variable, given a set of variables $X_{i}$ as follows:

$$
Q_{q}\left(y_{i t} / x_{i t}\right)=a_{q}+x_{i t} \cdot \beta_{q}+u_{i t} \cdot \alpha_{q}
$$

where $y_{i t}$ is the firm-level employment of firm $i$ through time; $x_{i t}$ is a vector of independent variables, including international trading activities and the covariates for firm and sector characteristics as discussed in the model specification section; and $u_{i t}$ represents unobservable factors such as product quality or management quality. Quantile 
Regression $(\mathrm{QR})$ considers the role of the regressors at various points on the conditional distribution of response dependent variable, for example, at the $25^{\text {th }}$ and $75^{\text {th }}$ percentiles. According to Cameron and Trivedi (2009, p. 207), the estimation of Equation (1) based on the $q^{\text {th }}$ quantile regression $\left(0<q^{\text {th }}<1\right)$, given a set of covariates $X_{i}$, is aimed at minimizing the absolute residual value, with the objective function as given below:

$$
\left.Q\left(\beta_{q}\right)=\min _{\beta} \sum_{i=1}^{n}\left[\mid y_{i t}-x_{i t} \beta_{q}\right]\right]=\min \left[\sum_{i: y_{i t} \geq x_{i} \beta} q\left|y_{i t}-x_{i t} \beta_{q}\right|+\sum_{i: y_{i t}<x_{i t} \beta}(1-q)\left|y_{i t}-x_{i t} \beta_{q}\right|\right]
$$

The QR shows how the treatment effect changes across specified percentiles of the entire distribution of employment. The QR estimator offers a detailed picture of the link between the outcome and the explanatory variables (Koenker and Hallock 2001). Many theoretical studies have considered capturing the unobserved factors through a fixed effects quantile approach (Canay 2011, Koenker 2004). Our two-step estimation procedure follows this approach. First, we estimate the conditional mean of $u_{i t}$ and then subtract this component from the original dependent variable. In the second step, we apply the traditional estimation of quantile regression with 1,000 replicated bootstraps.

\section{Empirical Results}

\section{A. The impact of international trade on firm-level employment}

In this section, we examine the conditional differences in firm-level employment and international trade at different percentiles and mean values. As shown in column 1 of Table 2, we find a statistically significant difference in employment growth between traders and non-traders. These results do not change much qualitatively when using fixed effect estimation and controlling for unobserved heterogeneity (column 2, Table 1). In addition, while exports have a positive relationship with firm employment growth, imports have a negative association. The evidence supports the predictions of the Heckscher-Ohlin-Samuelson model regarding that create a new jobs in the export sector and destruction of jobs in the import sector.

However, OLS regression estimates the conditional mean of the outcome distribution, which may cloud the role of international trade activities in firm-level employment at 
different points, since this linkage may be heterogeneous across the residual distribution of employment. Hence, we investigate the link between international trade activities and firm-level employment using the quantile approach.

Interestingly, as shown by column 3 of Table 1 and Figure 2, a different picture emerges when using quantile regression. The impact is heterogeneous across the residual distribution of firm employment. We find a positive relationship between traders and firm employment growth at the median and upper end of the distribution of firm employment. However, there is a negative link between traders and employment growth for firms with employment growth in the $10^{\text {th }}$ percentile. These results suggest that the averages approach clouds the role of export activities in firm employment growth at different points. Our results are a step forward in reconciling the mixed findings of previous studies reported in the literature. The results here suggest that the productivity advantages of traders compared with non-traders are realized for firms having high employment growth at the mean and upper percentiles. For firms with low employment growth in the $10^{\text {th }}$ percentile, these advantages are possibly offset by costs relating to trading activities in overseas markets, such as entry and advertisement costs. These results can be explained by the fact that traders in low percentiles have a negative association with firms' profit growth because the advantages of international traders are possibly offset by costs such as entry costs and advertisement costs in foreign markets (Vu et al. 2014). Hence, these firms cannot increase production and output, and this, in turn, reduces the employment.

Regarding other international trade activities (exporting or importing), Table 2 shows a significantly positive link between exporting firms and firm employment. This is consistent with the findings of several previous studies (Jenkin and Sen 2009, Sen 2009). They reflect the fact that in developing countries in general, and Vietnam in particular, the majority of exported goods are labor-intensive products (Kien 2015, Vu et al. 2013). Hence, a policy of export promotion has allowed these economies to exploit the comparative advantages of labor-intensive goods. Thus, expansion of exports becomes an important factor in employment growth. 
Table 1. International trade on firm-level employment

\begin{tabular}{|c|c|c|c|c|c|c|c|}
\hline \multirow{2}{*}{ Variables } & \multicolumn{2}{|c|}{ Mean approach } & \multicolumn{5}{|c|}{ Fixed effect quantile regression } \\
\hline & OLS & FE & q10 & $\mathrm{q} 25$ & q50 & $\mathbf{q 7 5}$ & q90 \\
\hline & $(1)$ & $(2)$ & (3) & (4) & $(5)$ & (6) & $(7)$ \\
\hline \multirow{2}{*}{ Both } & $0.2099 * *$ & $0.2403 * *$ & $-0.0206^{*}$ & $0.0312 * *$ & $0.1220 * *$ & $0.2337 * *$ & $0.3003 * *$ \\
\hline & $(0.005)$ & $(0.005)$ & $(0.009)$ & $(0.007)$ & $(0.005)$ & $(0.008)$ & $(0.011)$ \\
\hline \multirow{2}{*}{$\begin{array}{l}\text { Exporters } \\
\text { only }\end{array}$} & $0.0982 * *$ & $0.0500 * *$ & $0.2720 * *$ & $0.2535^{* *}$ & $0.2092 * *$ & $0.1444^{* *}$ & $0.0530 *$ \\
\hline & $(0.012)$ & $(0.011)$ & $(0.019)$ & $(0.013)$ & $(0.015)$ & $(0.021)$ & $(0.026)$ \\
\hline \multirow{2}{*}{$\begin{array}{l}\text { Importers } \\
\text { only }\end{array}$} & $-0.2635^{* *}$ & $-0.3090 * *$ & $-0.0992 * *$ & $-0.0691^{* *}$ & $-0.1172 * *$ & $-0.2569 * *$ & $-0.4059^{* *}$ \\
\hline & $(0.010)$ & $(0.009)$ & $(0.016)$ & $(0.017)$ & $(0.010)$ & $(0.015)$ & $(0.021)$ \\
\hline \multirow[t]{2}{*}{$\ln K$} & $0.1425^{* *}$ & $0.1480 * *$ & $0.0961 * *$ & $0.0897 * *$ & $0.0924 * *$ & $0.1441^{* *}$ & \\
\hline & $(0.002)$ & & & & & & \\
\hline \multirow[t]{2}{*}{ Lnwage } & $0.5397 * *$ & $0.5423 * *$ & $0.6708 * *$ & $0.6925^{* *}$ & $0.6456^{* *}$ & $0.5041^{* *}$ & $0.4360 * *$ \\
\hline & $(0.002)$ & $(0.001)$ & $(0.003)$ & $(0.002)$ & $(0.002)$ & $(0.003)$ & $(0.002)$ \\
\hline \multirow[t]{2}{*}{ Lnoutput } & & & & & & & \\
\hline & $(0.001)$ & $(0.001)$ & $(0.001)$ & $(0.001)$ & $(0.0$ & $(0.001)$ & $(0.002)$ \\
\hline \multirow[t]{2}{*}{ State } & $0.1874 * *$ & $0.2851^{* *}$ & $0.4436^{* *}$ & $0.4019^{* *}$ & $0.3763^{* *}$ & $0.3062 * *$ & $0.2922^{* *}$ \\
\hline & & & & & & & \\
\hline \multirow[t]{2}{*}{ Private } & $0.0485^{* *}$ & $0.1246 * *$ & $0.2661^{* *}$ & $0.1959 * *$ & $0.1066^{* *}$ & $0.0266^{* *}$ & -0.0205 \\
\hline & $(0.008)$ & $(0.007)$ & $(0.013)$ & $(0.009)$ & $(0.008)$ & $(0.010)$ & $(0.017)$ \\
\hline \multirow[t]{2}{*}{ High tech } & $-0.0253 * *$ & $-0.0276^{* *}$ & $-0.0555^{* *}$ & $0.0343 * *$ & & & \\
\hline & $(0.004)$ & $(0.003)$ & $(0.005)$ & $(0.004)$ & & $(0.006)$ & $(0.008)$ \\
\hline \multirow[t]{2}{*}{ Medium tech } & $-0.1451 * *$ & $-0.1440 * *$ & $-0.0851 * *$ & $-0.0563 * *$ & $-0.0974 * *$ & $-0.1988 * *$ & $-0.2542 * *$ \\
\hline & $(0.003)$ & $(0.003)$ & $(0.005)$ & $(0.002)$ & & $(0.004)$ & $(0.006)$ \\
\hline \multirow[t]{2}{*}{ Constant } & $-1.4711 * *$ & $-1.5656 * *$ & $-2.6078 * *$ & $-2.3956 * *$ & $-1.8853 * *$ & $-1.2407 * *$ & $-0.6750 * *$ \\
\hline & $(0.012)$ & $(0.011)$ & $(0.019)$ & $(0.015)$ & $(0.015)$ & $(0.015)$ & $(0.024)$ \\
\hline Observations & 199,742 & 199,742 & 199,742 & 199,742 & 199,742 & 199,742 & 199,742 \\
\hline R-squared & 0.862 & 0.864 & & & & & \\
\hline
\end{tabular}

(Note) The dependent variable is the natural log of labor. Clustered (by year and ind4) standard errors are in parentheses. + significant at $10 \%$; significant at $5 \%$;* significant at $1 \%$. All models control for year and province dummies. Base reference for ownership is foreign ownership, while low-tech sectors are the base group for type of technology sectors. 
Figure 2. The aggregate sector

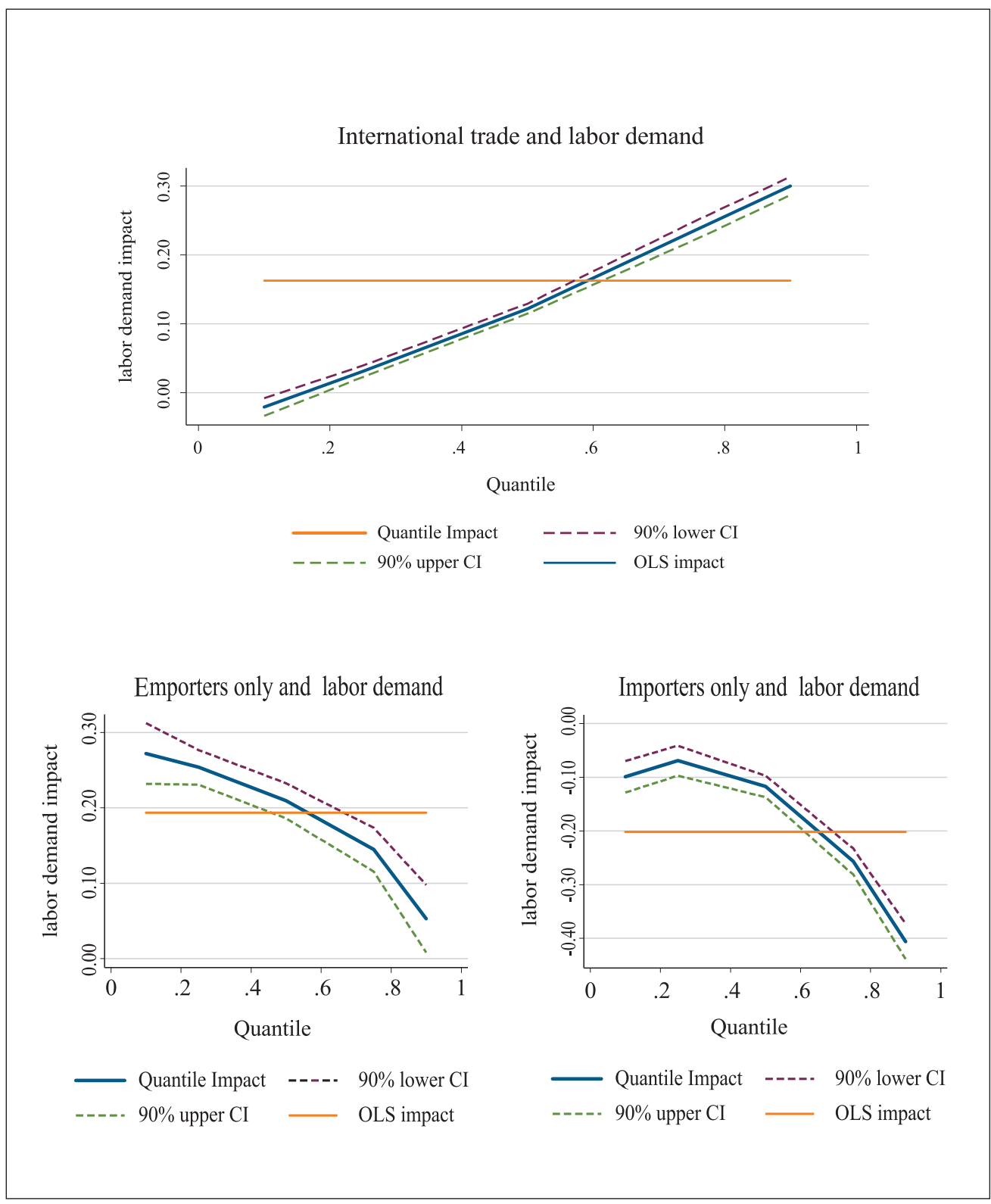

(Note) Figure 2 reflects decreasing trends of the impact of only importing/exporting activities and an increasing impact of international trade on firm-level employment growth. 
Table 2. Decomposing effects by low-technology sectors

\begin{tabular}{|l|c|c|c|c|c|}
\hline Variables & \multicolumn{5}{|c|}{ Fixed effect quantile regression } \\
\hline & $\mathbf{q 1 0}$ & $\mathbf{q 2 5}$ & $\mathbf{q 5 0}$ & $\mathbf{q 7 5}$ & $\mathbf{q 9 0}$ \\
\hline Ex_IM & $-0.0942^{* *}$ & $-0.0493^{* *}$ & $0.0531^{* *}$ & $0.1507^{* *}$ & $0.2506^{* *}$ \\
\hline & $(0.011)$ & $(0.008)$ & $(0.007)$ & $(0.013)$ & $(0.017)$ \\
\hline Export & $0.2829 * *$ & $0.3032^{* *}$ & $0.2575^{* *}$ & $0.1810^{* *}$ & 0.0371 \\
\hline & $(0.023)$ & $(0.017)$ & $(0.016)$ & $(0.023)$ & $(0.025)$ \\
\hline Import & $-0.0624^{*}$ & $-0.0430^{* *}$ & $-0.0693^{* *}$ & $-0.2248^{* *}$ & $-0.4377^{* *}$ \\
\hline & $(0.025)$ & $(0.017)$ & $(0.016)$ & $(0.017)$ & $(0.022)$ \\
\hline Constant & $-2.9199^{* *}$ & $-2.7165^{* *}$ & $-2.0569^{* *}$ & $-1.2714 * *$ & $-0.6173 * *$ \\
\hline & $(0.035)$ & $(0.022)$ & $(0.018)$ & $(0.025)$ & $(0.038)$ \\
\hline & & & & & \\
\hline Observations & 99,838 & 99,838 & 99,838 & 99,838 & 99,838 \\
\hline
\end{tabular}

(Note) The dependent variable is the natural log of labor. Clustered (by year and ind4) standard errors are in parentheses. + significant at $10 \%$; significant at $5 \%$; ** significant at $1 \%$. This model also controls for other independent covariates as in the model in Table 1.

Table 2 also shows a significant, negative link between imports and firm employment. This finding may be explained as follows. International trade in the early $21^{\text {st }}$ century is characterized by the boom in Chinese exports. Vietnam has felt a greater impact of cheap imports from China. Vietnam's imports through world trade increased from 0.22 percent in 1998 to 0.6 percent in 2009 (Doan et al. 2016), but Vietnam's imports from China have risen much faster. In addition, the Vietnamese economy is numerically dominated by Small and Medium Enterprises (SMEs), with 96\% of them typically having limited technology and a low level of development (Cuong, Sang, and Anh 2007, Doan, Nguyen, Vu, Tran, and Lim 2016, Vu, Holmes, Tran, and Lim 2016). Hence, cheap imports with similar technology, especially from China, could lead to intense competition within industries. Moreover, imports may displace domestic production, and this, in turn, may have negative effects on firm-level employment. A decreasing trend of importing and exporting activities in firm employment growth can be further demonstrated using confidence intervals, as shown in Figure 2. 
In terms of firm characteristics, Table 1 shows that the impacts of capital and output are clearly reflected in the regression results. Firms with larger output enjoy higher job gains, and firms with more capital have a positive association with job creation in firms. A negative relationship between firm-level employment and firms in the medium- and high-tech sectors implies that firms in the low-tech sector create more jobs than their counterparts in other sectors.

\section{B. Decomposing effects}

Firm-level international trade behavior varies greatly based on the level of technology (Ministry of Industry and Trade of Vietnam and United Nations Industrial Development Organization 2011). Hence, we examine the link between participation in international trade and firm-level employment in each subgroup at various technology levels. The results are reported in Table 2, Table 3, and Table 4.

In terms of the impact of the main variable of interest, the empirical results indicate a statistically significant and negative influence of increased import penetration on employment change. The empirical evidence is also in line with the findings of recent studies (Edwards 2004, Jenkins and Sen 2009), which conclude that rising import penetration has a significantly negative impact on employment growth. A negative impact of imports on employment can stem from several reasons. Vietnamese firms typically have low technology and a low level of development; hence, cheap imports from China may create intensified competition within industries and have a negative effect on firm employment. Vietnamese firms face direct competition pressure from imports, especially from China. Imports displace domestic production, and this may have a negative effect on firm employment (Edwards and Jenkins 2013).

These findings, however, are inconsistent with the empirical evidence presented by Kien and Heo (2009), who suggest that import penetration has a positive and insignificant effect on employment. One reason for this different finding by Kien and Heo (2009) could be that their study is based on industry-level data, which are more likely to be biased, being aggregated data (Kasahara and Rodrigue 2008). Meanwhile, our study is based on firm-level data that capture firm heterogeneity. 


\section{Figure 3. The low-technology sector}

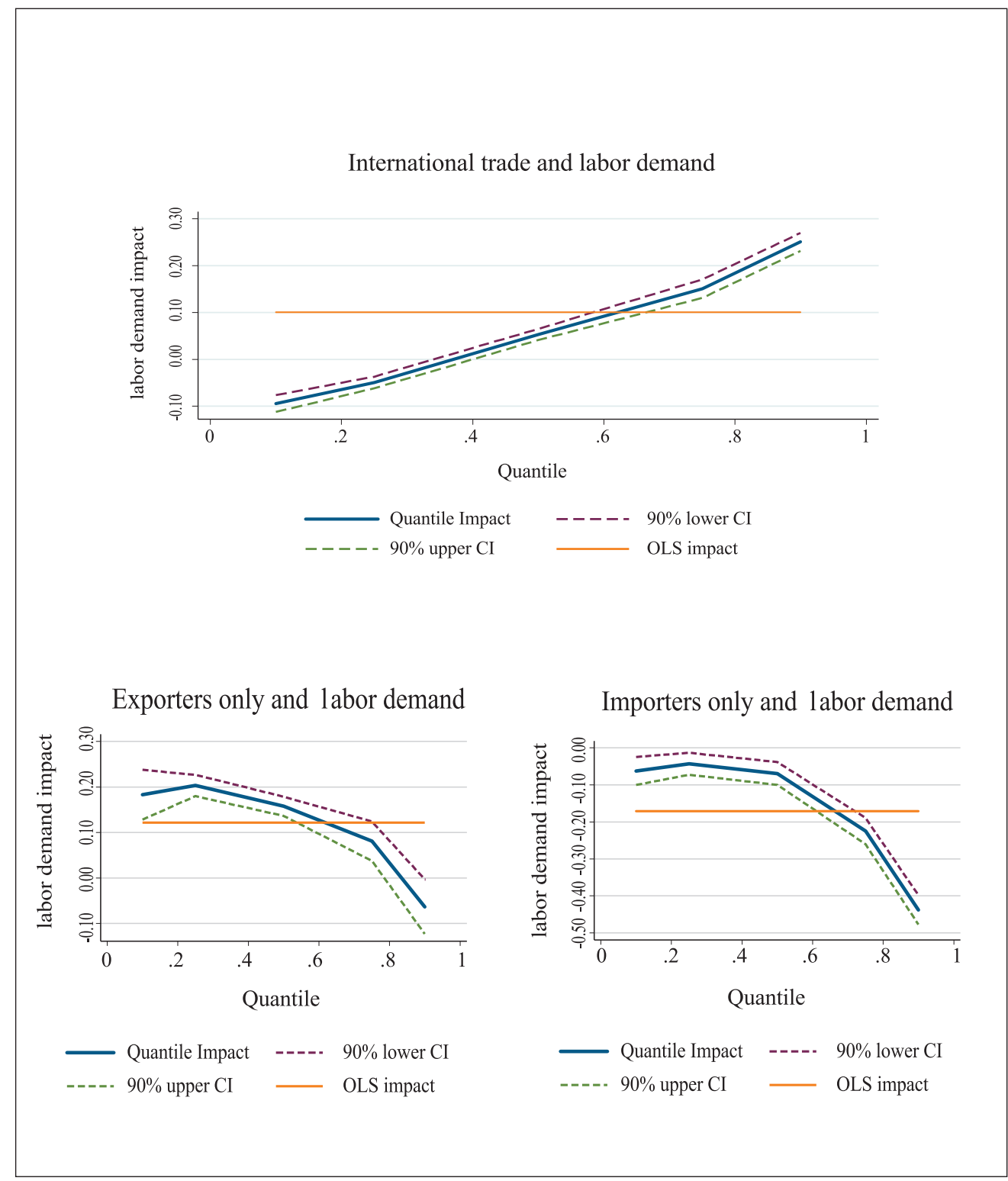

(Note) Figure 3 reflects various trends of the impact of importing and exporting activities on firm-level employment growth in the low-tech sector. 
On the role of international trade activities in firm-level employment, we see from Table 2 that there is a negative and significant link between firms having low employment at the firm-level in the lower quartiles and international trade activities. In addition, there is a positive link between an increase in exports and the entire distribution of employment. Figure 3 further demonstrates these results when confidence intervals are used.

Table 3. Decomposing effects by medium-technology sectors

\begin{tabular}{|l|c|c|c|c|c|}
\hline \multirow{2}{*}{ Variables } & \multicolumn{5}{|c|}{ Fixed effect quantile regression } \\
\cline { 2 - 6 } & $\mathbf{q 1 0}$ & $\mathbf{q 2 5}$ & $\mathbf{q 5 0}$ & $\mathbf{q 7 5}$ & $\mathbf{q 9 0}$ \\
\hline & $\mathbf{( 1 )}$ & $\mathbf{( 2 )}$ & $\mathbf{( 3 )}$ & $\mathbf{( 4 )}$ & $\mathbf{( 5 )}$ \\
\hline Ex_IM & $-0.0549^{* *}$ & $-0.0180+$ & $0.0767^{* *}$ & $0.2036^{* *}$ & $0.2591^{* *}$ \\
\hline Export & $(0.012)$ & $(0.010)$ & $(0.012)$ & $(0.015)$ & $(0.021)$ \\
\hline & $0.1570^{* *}$ & $0.1429^{* *}$ & $0.1677^{* *}$ & $0.1486^{* *}$ & 0.0621 \\
\hline Import & $(0.041)$ & $(0.026)$ & $(0.033)$ & $(0.053)$ & $(0.062)$ \\
\hline & 0.0141 & 0.0053 & $-0.0687^{* *}$ & $-0.1818^{* *}$ & $-0.2936^{* *}$ \\
\hline Constant & $(0.028)$ & $(0.013)$ & $(0.015)$ & $(0.022)$ & $(0.034)$ \\
\hline & $-2.5939^{* *}$ & $-2.3731^{* *}$ & $-1.9736^{* *}$ & $-1.4705^{* *}$ & $-1.0959^{* *}$ \\
\hline & $(0.029)$ & $(0.019)$ & $(0.024)$ & $(0.028)$ & $(0.040)$ \\
\hline Observations & 59,879 & 59,879 & 59,879 & 59,879 & 59,879 \\
\hline
\end{tabular}

(Note) The dependent variable is the natural log of labor. Clustered (by year and ind4) standard errors are in parentheses. + significant at $10 \%$; significant at $5 \%$;* significant at $1 \%$. This model also controls for other independent covariates as in the model in Table 1.

Table 3 shows the results of regressions for firms in the medium-tech sector. We observe a negative impact of imports on firm-level employment in the higher percentile of employment distribution. However, there is not much of a qualitative change in the estimated coefficient of the impact of traders and exporters on firm-level employment when compared with firms in the low-technology sector. The impact of international trade on firm-level employment are further demonstrated through the use of confidence intervals, as shown in Figure 4. 


\section{Figure 4. The medium-technology sector}

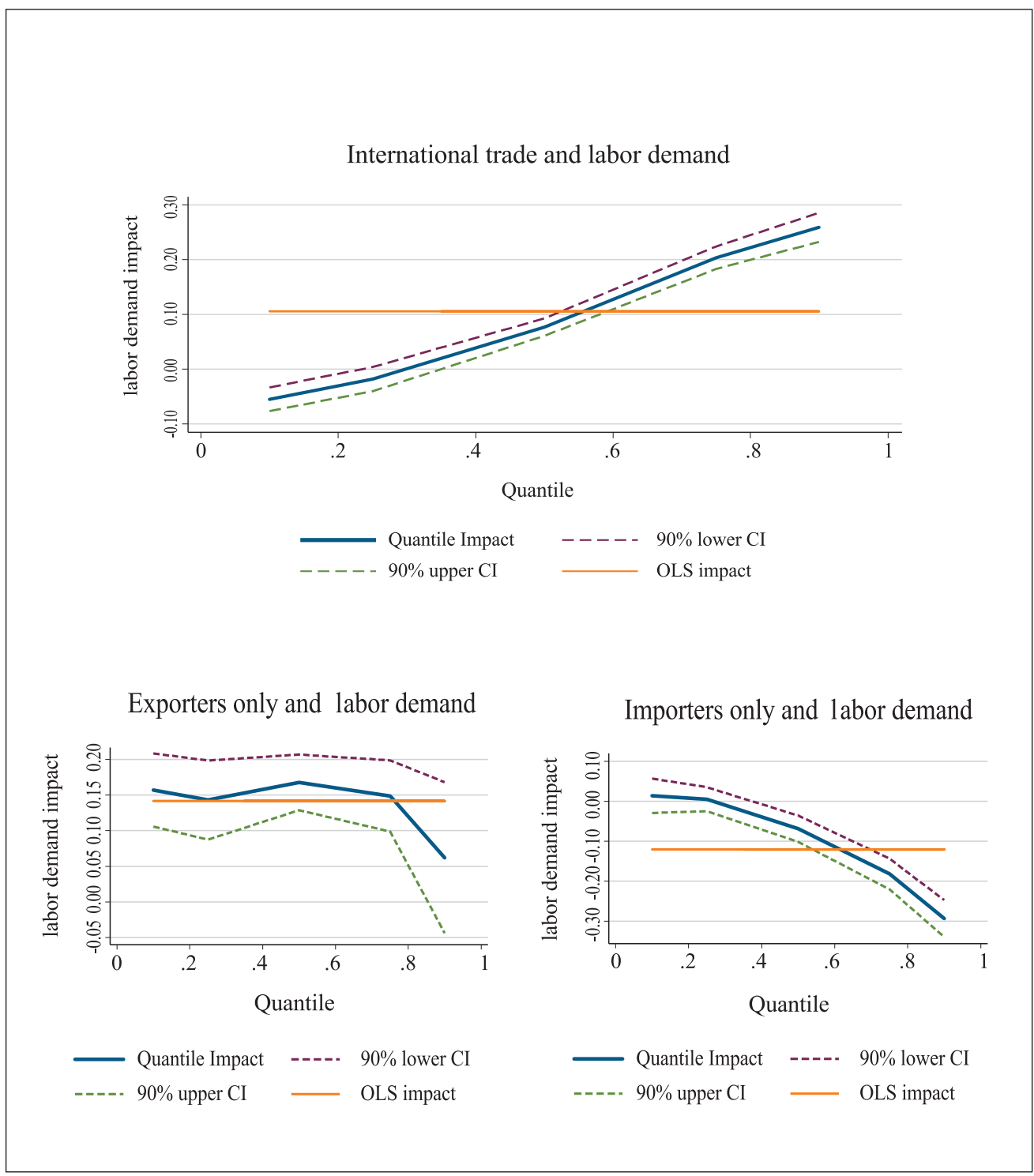

(Note) Figure 4 reflects various trends of the impact of importing and exporting activities on firm-level employment growth in the medium-tech sector. 
Table 4. Decomposing effects by high-technology sectors

\begin{tabular}{|l|c|c|c|c|c|}
\hline \multirow{2}{*}{ Variables } & \multicolumn{5}{|c|}{ Fixed effect quantile regression } \\
\cline { 2 - 6 } & $\mathbf{q 1 0}$ & $\mathbf{q 2 5}$ & $\mathbf{q 5 0}$ & $\mathbf{q 7 5}$ & $\mathbf{q 9 0}$ \\
\hline Ex_IM & $(1)$ & $(2)$ & $(3)$ & $(4)$ & $(5)$ \\
\hline & $0.2586^{* *}$ & $0.3529^{* *}$ & $0.3824^{* *}$ & $0.4277^{* *}$ & $0.4113^{* *}$ \\
\hline Export & $(0.022)$ & $(0.018)$ & $(0.014)$ & $(0.017)$ & $(0.021)$ \\
\hline & $0.1967 * *$ & $0.1120^{* *}$ & $0.0759^{* *}$ & $0.0664+$ & 0.0249 \\
\hline Import & $(0.037)$ & $(0.030)$ & $(0.024)$ & $(0.034)$ & $(0.035)$ \\
\hline & $-0.4232^{* *}$ & $-0.2975^{* *}$ & $-0.2690^{* *}$ & $-0.3150^{* *}$ & $-0.3827^{* *}$ \\
\hline Constant & $(0.077)$ & $(0.043)$ & $(0.028)$ & $(0.043)$ & $(0.050)$ \\
\hline & $-2.0339^{* *}$ & $-1.7753^{* *}$ & $-1.4995^{* *}$ & $-1.1481^{* *}$ & $-0.6772^{* *}$ \\
\hline & $(0.050)$ & $(0.039)$ & $(0.032)$ & $(0.034)$ & $(0.054)$ \\
\hline Observations & 34,514 & 34,514 & 34,514 & 34,514 & 34,514 \\
\hline
\end{tabular}

(Note) The dependent variable is the natural log of labor. Clustered (by year and ind4) standard errors are in parentheses. + significant at 10\%; * significant at 5\%; ** significant at 1\%. This model also controls for other independent covariates as in the model in Table 1.

Finally, the effect of international trade on firm-level employment may also be heterogeneous across firm size groups. Firm size can represent differences in efficiency and firm competitiveness (Jovanovic 1982). Hence, we examine the link between international trade and firm-level employment in sub-samples according to firm size. The estimates show that there is a negative relationship with employment for firms in the low employment percentile but a positive relationship with firms in the high employment percentile for small and very small firms but not for large firms. This paper also examines the role of international trade activities in labor demand in different regions of Vietnam. The results show that international trade is negatively and insignificantly linked with employment for firms in the low employment percentile but positively related to firms in the high employment percentile in Vietnam's northwest region. This region is Vietnam's poorest, with the international trade turnover accounting for just $0.53 \%$ of the country's total trade turnover (GSO 2015). In addition, the per capita export turnover of this region is still relatively low, at 182 US dollars per person, while the country's average is 1,656 US dollars per person. In this context, the above findings show that only firms participating in international trade in the high percentiles may see an impact on their labor demand. 
Figure 5. The high-technology sector

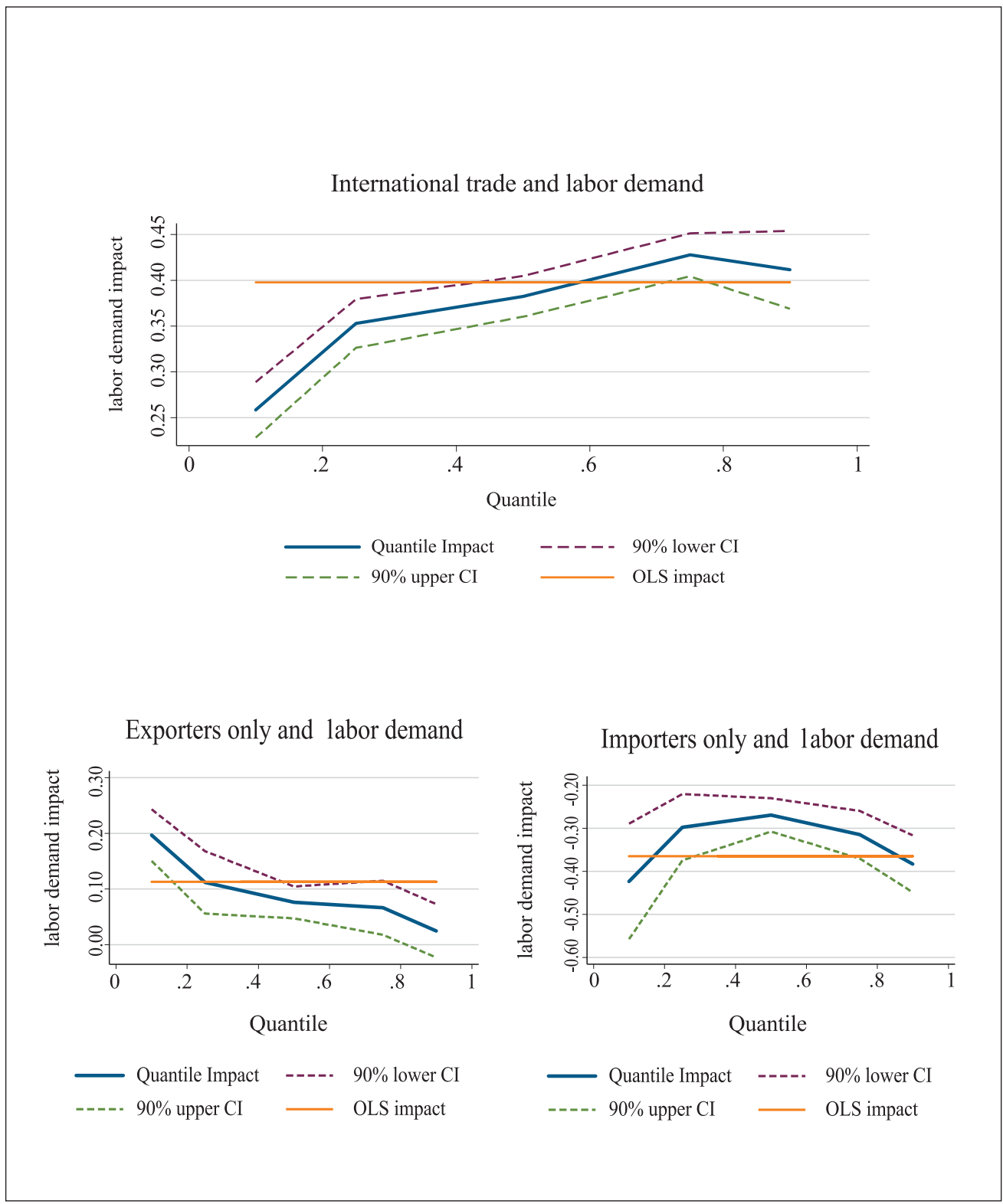

(Note) Figure 5 reflects various trends of the impact of importing and exporting activities on firm-level employment growth in the high-tech sector. 


\section{Policy Implications}

This paper examines job gains and job losses from imports and exports. Many studies have dealt with the effects of international trade on employment, but most use macrolevel data on countries or industries. In addition, most of these studies use the mean approach and therefore fail to identify the effects of international trade on firm-level employment.

Using a unique micro panel dataset on Vietnamese firms and fixed effect quantile regression, this study examines, for the first time, the effects of international trade on firm-level employment. This approach overcomes the shortcomings of previous studies by controlling for the heterogeneity of firms, unobservable characteristics, and heterogeneous populations. Specifically, using a quantile treatment approach, we provide evidence of a positive association between international trade and firm-level employment for firms with high employment levels in the higher quantiles but a negative link for firms with low employment in the lower quantiles. These findings imply that the role of international trade activities in firm-level employment varies at different points on the employment distribution; thus, we reconcile the mixed findings in the literature.

Several caveats are in order. First, the role of international trade in employment may vary depending on imports or exports of final or intermediate goods. Moreover, the effect of imports on employment may differ according to whether international trade activities happen with developing or developed countries. The impact may also vary based on whether the impact of international trade on employment is being investigated through supply chains. However, data limitations prevent us from exploring such scenarios, and these explorations await future research.

Received 30 May 2017, Revised 5 July 2017, Accepted 26 July 2017

\footnotetext{
*Acknowledgements: This paper is a part of Project Number KHCN-TB.18X/13-18, which is led by Assoc. Prof. Hoi Van Ha and funded by Vietnam National University - Hanoi under the Science and Technology Program for the Sustainable Development of the Northwest Region.
} 


\section{References}

Buchinsky, Moshe. "Changes in the US wage structure 1963-1987: Application of quantile regression". Econometrica: Journal of the Econometric Society 62(2) 1994: 405-458.

Cameron, A. C., \& Trivedi, P. K. Microeconometrics using stata. College Station, TX: Stata Press, 2009.

Canay, I. A. "A simple approach to quantile regression for panel data". The Econometrics Journal, 14(3) 2011: 368-386.

Chand, S., \& Sen, K. "Trade liberalization and productivity growth: evidence from Indian manufacturing”. Review of Development Economics 6(1)2002: 120-132.

Cuong, T. T., Sang, L., \& Anh, N. "Vietnam's small-and medium-sized enterprises development: characteristics, constraints and policy recommendations". SME in Asia and Globalization, ERIA Research Project Report (2007) Accessed April 15, 2017. http://www.vnep.org.vn/Upload/Vietnam\%E2\%80\%99s\%20Small\%20 and $\% 20$ Medium $\% 20$ Sized $\% 20$ Enterprises\%20Development_Characteristics, $\% 20$ Constraints\%20and\%20Policy\%20Recommendations_Sang_KimAnh.PDF

David, H., Dorn, D., \& Hanson, G. H. "The China syndrome: Local labor market effects of import competition in the United States". The American Economic Review, 103(6) 2013: 2121-2168.

Doan, T., Nguyen, S., Vu, H., Tran, T., \& Lim, S. "Does rising import competition harm local firm productivity in less advanced economies? Evidence from the Vietnam's manufacturing sector". The Journal of International Trade \& Economic Development, 25(1) 2016: 23-46.

Edwards, L. "A firm level analysis of trade, technology and employment in South Africa". Journal of International Development 16(1) 2004: 45-61.

Edwards, L., \& Jenkins, R. "The impact of chinese import penetration on the south african manufacturing sector" (2013) Accessed January 10, 2017. https://www.uea. ac.uk/documents/439774/0/Edwards+Jenjkins+SALDRU.pdf/82f05bfc-bf8b-4af1- 
b843-bb522695c6d6.

Fu, X., \& Balasubramanyam, V. Exports, FDI, growth of small rural enterprises and employment in China: ESRC Centre for Business Research: University of Cambridge, 2004.

Greenaway, D., Hine, R. C., \& Wright, P. "An empirical assessment of the impact of trade on employment in the United Kingdom". European Journal of Political Economy 15( 3) 1999: 485-500.

Griliches, Z., and J. Hausman. "Errors in Variables in Panel Data." Journal of Econometrics 31 (1) 1986: 93-118.

Halpern, L., M. Koren, and A. Szeidl. 2005. "Imports and Productivity", 2005. Accessed March 2017. http://papers. ssrn.com/sol3/papers.cfm?abstract_id = 785127

Helpman, E., Itskhoki, O., \& Redding, S. "Inequality and unemployment in a global economy". Econometrica 78(4) 2010:1239-1283.

Ibsen, R., Warzynski, F., \& Westergård-Nielsen, N.“Employment Growth and International Trade: A Small Open Economy Perspective”, 2009. Accessed January 10, 2017.http://www.hha.dk/nat/wper/09-9_fwanwn.pdf.

Jenkins, R., \& Sen, K. "International trade and manufacturing employment in the South: four country case studies". Oxford Development Studies 34 (3) 2009: 299-322.

Jovanovic, B. "Selection and the evolution of industry". Econometrica 50(3) 1982: 649-670.

Kasahara, H., \& Rodrigue, J. "Does the use of imported intermediates increase productivity? Plant-level evidence”. Journal of Development Economics 87(1) 2008:106-118.

Kien, T. N., \& Heo, Y. "Impacts of trade liberalization on employment in Vietnam: A system generalized method of moments estimation". The Developing Economies 47(1) 2009: 81-103. 
Kien, N. T. "Manufacturing exports and employment generation in Vietnam". Southeast Asian Journal of Economics, 3(2) 2015: 1-21.

Kizhakethalackal, E. T., Mukherjee, D. and Alvi, E. "Quantile regression analysis of health-aid and infant mortality: a note". Applied Economics Letters, 20 (2) 2013: 11971201.

Ko, K., Rangkakulnuwat, P., \& Paweenawat, S. "The Effect of International Trade on Labor Demand in ASEAN5". Economics Bulletin, 35(2) 2015: 1034-1041.

Koenker, R. "Quantile regression for longitudinal data”. Journal of Multivariate Analysis, 91(1) 2004: 74-89.

Koenker, R., \& Hallock, K. “Quantile regression: An introduction”. Journal of Economic Perspectives 15(4) 2001: 43-56.

Kurz, C., \& Senses, M. Z. "Importing, exporting, and firm-level employment volatility”. Journal of International Economics, 98 (3)2016: 160-175.

Mion and L. Zhu, "Import Competition from and Outsourcing to China: A Curse or blessing for Firms?”. CEP Discussion Paper No.1038: Centre for Economic Performance, The London School of Economics and Political Science, 2010.

Milner, C., \& Wright, P. 'Modelling labour market adjustment to trade liberalisation in an industrialising economy". The Economic Journal 108(447) 1998: 509-528.

Moulton, B.R. "An Illustration of a Pitfall in Estimating the Effects of Aggregate Variables on Micro Units." Review of Economics and Statistics 72 (2) 1990: 334-338.

Ministry of Industry and Trade of Vietnam, [MITV], \& United Nations Industrial Development Organisation, [UNIDO].Vietnam industrial competitiveness report, 2011. Hanoi, Vietnam.

Sen, K. "International trade and manufacturing employment: Is India following the footsteps of Asia or Africa?" Review of Development Economics 13(4) 2009: 765-777.

Sen, K. "Globalisation and employment in Bangladesh and Kenya." Globalization, Production and Poverty Discussion Paper, 2008. Accessed January 24, 2017. http:// 
bdresearch.org/home/attachments/article/604/Globalisation\%20and\%20Employment. pdf.

Turrini, A. "International trade and labour market performance: major findings and open questions". United Nations Publications, 2002.

Vu, H. V., Holmes, M., Tran, T. Q., \& Lim, S. "Firm exporting and productivity: what if productivity is no longer a black box." Baltic Journal of Economics 16(2) 2016: 95113.

Vu, H., Holmes, M., Lim, S., \& Tran, T. "Exports and profitability: a note from quantile regression approach". Applied Economics Letters 21(6) 2014: 442-445.

Vu, H., Lim, S., Holmes, M., \& Doan, T. "Firm exporting and employee benefits: first evidence from Vietnam manufacturing SMEs". Economics Bulletin 33(1)2013: 519535.

Wooldridge, J. M. Econometric analysis of cross section and panel data. Cambridge, MA: The MIT Press, 2002.

Wagner, J. "Export intensity and plant characteristics: What can we learn from quantile regression?" Review of World Economics 142(1) 2006: 195-203. 


\begin{tabular}{|c|c|c|c|c|c|c|c|c|c|c|c|c|c|}
\hline ह & $\stackrel{\infty}{+}$ & ๗ે & $\begin{array}{l}8 \\
\dot{0} \\
\dot{0}\end{array}$ & 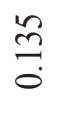 & \begin{tabular}{l} 
Iิ \\
\multirow{-}{*}{}
\end{tabular} & $\stackrel{\infty}{-}$ & $\stackrel{i}{i}$ & $\frac{2}{2}$ & în & $\frac{8}{0}$ & $\stackrel{\stackrel{\leftrightarrow}{+}}{\circ}$ & 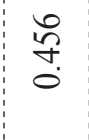 & กิ \\
\hline$\sum_{\Sigma}^{E}$ & $\begin{array}{l}\text { ले } \\
\text { m}\end{array}$ & $\stackrel{m}{0}$ & $\underset{O}{O}$ & $\stackrel{\infty}{0}$ & $\underset{\infty}{\infty}$ & $\begin{array}{l}\hat{2} \\
\hat{n}\end{array}$ & $\frac{\mathfrak{\infty}}{\stackrel{一}{r}}$ & $\stackrel{m}{0}$ & ڤ̆ & ஸ̂ல & $\begin{array}{l}\bar{R} \\
\stackrel{n}{0}\end{array}$ & $\begin{array}{l}\text { సे } \\
\text { ஸे }\end{array}$ & $\frac{N}{0}$ \\
\hline อิ & 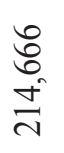 & 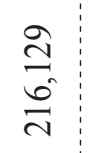 & $\begin{array}{l}\text { ปิ } \\
\frac{\sigma}{2}\end{array}$ & $\begin{array}{l}\stackrel{\Xi}{\sigma} \\
\stackrel{0}{v}\end{array}$ & 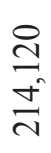 & $\frac{\infty}{\stackrel{\infty}{\approx}}$ & 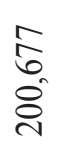 & 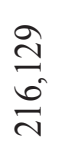 & $\begin{array}{l}\text { ปิ } \\
\frac{\sigma}{2}\end{array}$ & $\begin{array}{l}\stackrel{2}{\sigma} \\
\underset{\sim}{2}\end{array}$ & $\begin{array}{l}\stackrel{\overbrace{}}{二} \\
\underset{\sim}{\sim}\end{array}$ & $\begin{array}{l}\stackrel{2}{\sigma} \\
\stackrel{0}{\sim}\end{array}$ & $\begin{array}{l}\text { ते } \\
\frac{0}{2}\end{array}$ \\
\hline อ气 & 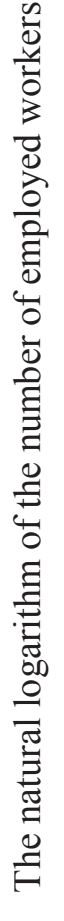 & 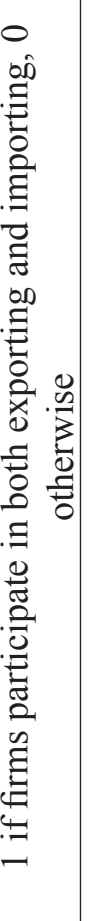 & 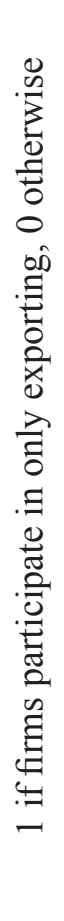 & 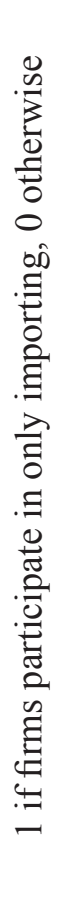 & 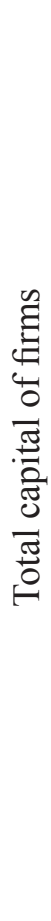 & 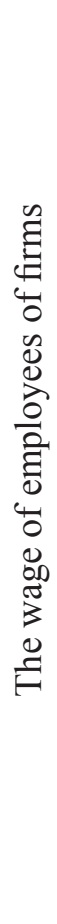 & 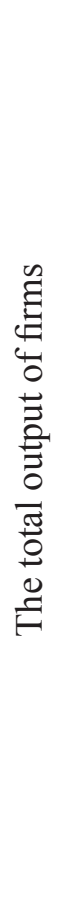 & 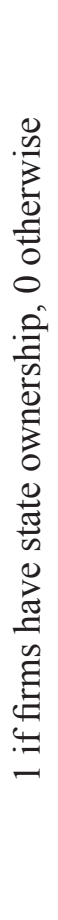 & 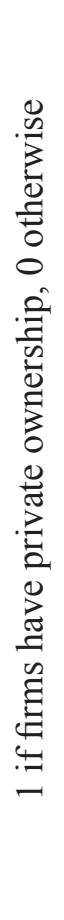 & 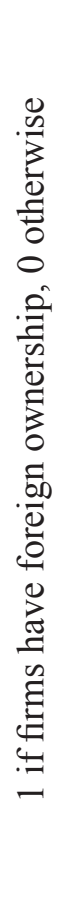 & 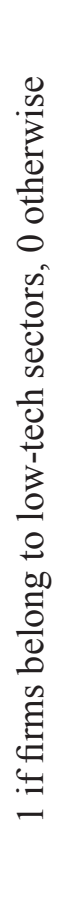 & 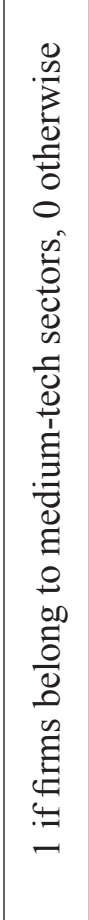 & 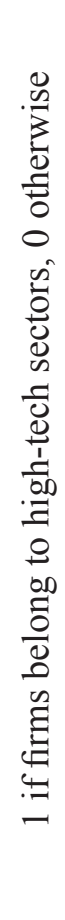 \\
\hline$\frac{\frac{\tilde{e}}{0}}{\frac{\pi}{\sigma}}$ & $\stackrel{\mathbb{J}}{\mathfrak{J}}$ & 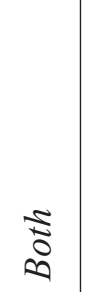 & 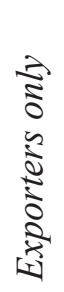 & 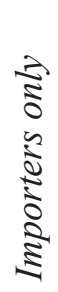 & $\Xi$ & 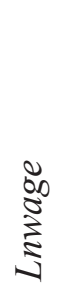 & 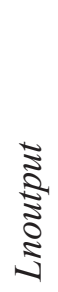 & $\underset{\tilde{\varpi}}{\tilde{\varpi}}$ & 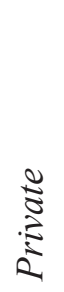 & $\begin{array}{l}.00 \\
0 \\
0 \\
0\end{array}$ & 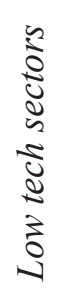 & 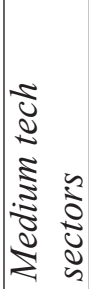 & 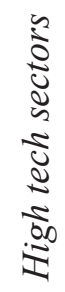 \\
\hline
\end{tabular}




\section{Appendix 2: Technology level industry groups}

\section{Group 1: Low technology}

D15: Food and beverages

D16: Cigarettes and tobacco

D17: Textile products

D18: Wearing apparel, dressing, and dying of fur

D19: Leather and products of leather; leather substitutes; footwear

D20: Wood and wood products, excluding furniture

D21: Paper and paper products

D22: Printing, publishing, and reproduction of recorded media

D23: Coke and refined petroleum products and nuclear fuel

D36: Furniture and other products not classified elsewhere

D37: Recycled products

\section{Group 2: Medium technology}

D24: Chemicals and chemical products

D25: Rubber and plastic products

D26: Other non-metallic mineral products

D27: Iron, steel, and non-ferrous metal basic industries

D28: Fabricated metal products, except machinery and equipment

\section{Group 3: High technology}

D29: Machinery and equipment

D30: Computer and office equipment

D31: Electrical machinery apparatus, appliances, and supplies

D32: Radios, televisions, and telecommunication devices

D33: Medical equipment, optical instruments

D34: Motor vehicles and trailers

D35: Other transport equipment 


\section{Appendix 3: Theoretical foundation of the model}

Following Greenaway, Hine, and Wright (1999) and Milner and Wright (1998), the model specification of the impact of import activities on employment begins by using a simple Cobb-Douglas production function for firm $i$ at time $t$ :

$Q_{i t}=A^{\lambda} K_{i t}^{\alpha} L_{i t}^{\beta}$

where $Q_{i t}=$ real output, and the two input factors are $K i t=$ capital and $L i t=$ labor.

$$
\begin{aligned}
& \frac{\partial Q_{i t}}{\partial K_{i t}}=\alpha A^{\lambda} K_{i t}^{\alpha-1} L_{i t}^{\beta} \\
& \frac{\partial Q_{i t}}{\partial L_{i t}}=\beta A^{\lambda} K_{i t}^{\alpha-1} L_{i t}^{\beta-1}
\end{aligned}
$$

A firm following a profit-maximizing strategy will choose that level of labor and capital where the marginal revenue of labor $\left(M R P_{L}\right)$ is equal to the wage $(w)$ and the marginal revenue of capital $\left(M R P_{K}\right)$ is equal to the cost $(c)$.

Multiply (2) with unit price (P): $\quad M R P_{L}=p \beta A^{\lambda} K_{i t}^{\alpha} L_{i t}^{\beta-1}=w$

And (3) with unit price $(P): \quad M R P_{K}=p \alpha A^{\lambda} K_{i t}^{\alpha-1} L_{i t}^{\beta}=c$

From Equation (4) : $\quad K_{i t}^{\alpha}=\frac{w}{p \beta A^{\lambda} L_{i t}^{\beta-1}}$

From Equation (5): $\quad K_{i t}^{\alpha-1}=\frac{c}{p \alpha A^{\lambda} L_{i t}^{\beta}}$

From Equation (7): $\quad K_{i t}^{\alpha}=\frac{c K_{i t}}{p \alpha A^{\lambda} L_{i t}^{\beta}}$ 
But Equation (A6) = Equation (A8); solving for $K: \quad K_{i t}=\frac{w \alpha}{c \beta} \cdot L_{i t}$

Substituting $K_{i t}$ in Equation (A9) into Equation (A10): $Q_{i t}=A^{\lambda}\left(\frac{w \alpha}{c \beta} \cdot L_{i t}\right)^{\alpha} L_{i t}^{\beta}$

From Equation (A10): $\quad Q_{i t}=A^{\lambda} w^{\alpha} L_{i t}^{\alpha} L_{i t}^{\beta} c^{-\alpha} \beta^{-\alpha}$

Taking logarithms and rearranging the terms on the right side of Equation (11):

$\ln L_{i t}=\varphi_{0}+\varphi_{1}$ in $\left(\frac{w}{c}\right)+\varphi_{2} \ln \left(Q_{i t}\right)$

where $\varphi_{0}=-(\lambda \ln A+a \ln a-a \ln \beta) /(a+\beta)$

$$
\varphi_{1}=-\alpha /(\alpha+\beta) \quad, \quad \varphi_{2}=1 /(\alpha+\beta)
$$

According to Greenaway et al. (1999), A is assumed to change with international activities. Therefore, Equation (A12) is written as follows:

$\ln L_{i t}=\phi_{0}+\phi_{1} \ln (w / c)+\phi_{2} \ln \left(Q_{i t}\right)+\phi_{3}$ International_ Trade $_{i t}$

(Note) (i) OLS represents ordinary least squares, while FE is a fixed effect estimation.

(ii) The foundation for the theoretical model is set out in Appendix 3.

(iii) Small and very small firms have less than 200 workers.

(iv) These estimation results are available on request. 